\title{
Tidal Influence on Water Quality of Kapuas Kecil River Downstream
}

\author{
Rizki Purnaini ${ }^{1 *}$, Sudarmadji ${ }^{2}$ and Suryo Purwono ${ }^{3}$ \\ ${ }^{1}$ Doctoral Program of Environmental Science, School of Postgraduate Studies, Gadjah Mada University, Yogyakarta - Indonesia \\ ${ }^{2}$ Department of Environmental Geography, Faculty of Geography, Gadjah Mada University, Yogyakarta - Indonesia \\ ${ }^{3}$ Department of Chemical Engineering, Faculty of Engineering, Gadjah Mada University, Yogyakarta - Indonesia
}

\begin{abstract}
The Kapuas Kecil River is strongly influenced by tidal, in the dry season the intrusion of surface water is often a problem for the WTP because it causes the change of raw water quality to be processed. The purpose of this study was to examine the effect of sea tides on water quality of the Kapuas Kecil River. The study was conducted in Kapuas River downstream along $\pm 30 \mathrm{~km}$ from the upper boundary to the estuary. Water sampling is carried out during the dry and rainy season, when the tidal conditions at 7 (seven) locations of the monitoring station. Descriptive analysis methods and regressioncorrelation statistics are used to determine the effect of tides on water quality in Kapuas River downstream. In general, the water quality of the Kapuas Kecil River has exceeded the criteria of first class water quality, ie water that can be used for drinking water. The status of water quality of the Kapuas Kecil River based on the pollution index calculation shows the condition of the river is "mild to medium pollutants". The result of multiple linear regression analys is got the value of coefficient of determination (adjusted $\mathrm{R}$ square) $=0,760$, which in whole show that independent variable (tidal and distance) influence to dependent variable (value of TDS) equal to $76 \%$.
\end{abstract}

\section{Introduction}

River is one of the water resources that has many functions and benefits for humans, but inevitably the river also serves as a place to dump the remains of human activities both solid waste and liquid waste. The entry of various kinds of discharges into the river either directly or indirectly can lead to a decrease in river water quality.

The ability of self-purification of the river will decrease with the influx of pollutants from various pollutant sources with the increase of population so that the river becomes polluted and can not be utilized again as intended. As one source of raw water, surface water must be maintained in order to maintain its quality to be utilized in accordance with its allocation, therefore water quality monitoring and policy are necessary in water quality management and water pollution control.

The Kapuas Kecil River as part of the Kapuas River Basin that flows from upstream to downstream through Kubu Raya District, Pontianak City and Mempawah District. Kapuas Kecil River divides and passes through Pontianak City before heading to estuary to Karimata Strait. This river passes through the city with densely populated settlements and various community activities such as trade, services, and large-small industries. Pontianak City has many small rivers that form naturally or artificially that serves as a drainage and domestic sewage. The main sources of pollutants entering Kapuas Kecil River downstream come from domestic waste settlements, trade and service activities, large and small industrial waste, fish cages and urban runoff.

Kapuas Kecil River is the source of raw water for Pontianak City WTP and Sei Raya City WTP. Some people in the city still use river water directly for daily utility. The Kapuas Kecil River is strongly influenced by tidal, in the dry season the intrusion of surface water is often a problem for the WTP because it causes the change of raw water quality to be processed.

River is dynamic so the water quality is also dynamic. Fluctuations in water quality are caused by the type and amount of pollutants from various sources of pollutants and diverse areas and the process of physics, chemistry and biology in the waters. In addition, the hydrological conditions of the river and the effect of fluctuating tides will also affect water quality.

River flows and seasonal changes are one of the important parameters in circulation in the estuary. River flow depends on the characteristics of hydrology and the watershed. In the rainy season the flow of large flow, while in the dry season is small. In general, river discharge is much smaller than the discharge caused by the influence of the tides. The effect of flow discharge is

*Corresponding author: rizkipurnaini@yahoo.co.id 
more dominant in the upstream estuary compared with downstream. At the time of flooding, river discharge pushes pollutants into the sea, while at a small discharge the pollutant moves upstream. Tidal currents affect the shifting of pollutants along the estuary, moving upstream at high tide and downstream at low tide [1].

Water quality can be highly dependent on river flow conditions. River flow affects water quality in several ways, namely: 1). Dilution; Large flow volumes can dilute the concentration of pollutants being dumped into the river. 2). Residence time; High flow rates can reduce the residence time and affect the amount of material that can be produced or degraded in the river. 3). Mixing; High flow velocity leads to increased mixing in rivers, enhanced river assimilation capabilities, and reduced gradient of pollutant concentrations. 4). erosion; High flow rates can erode the material along the flow [2].

This research was conducted with the aim to study the influence of tides on water quality in the lower Kapuas River downstream so as to get description of water quality characteristics of the river and the ability of the river to accommodate incoming pollutants, so that the sustainability of river utilization can be maintained.

\section{Materials and Methods}

The study was conducted in August 2016 to represent the dry season and January 2017 to represent the rainy season in the Kapuas Kecil River downstream of \pm 30 $\mathrm{km}$ from the upstream boundary of the research site to the estuary. Upper boundary of research location is intake location of Sei Raya WTP, while the downstream boundary is mouth of river. Sampling using purposive sampling method at 7 (seven) location of monitoring station during tidal condition (Fig. 1).

The data used in this study are primary data including water quality parameters :temperature, $\mathrm{pH}$, TSS, TDS, BOD, COD, DO, N, P, and salinity; hydrometry; and bathymetry. Secondary data include tidal forecast and land use and drainage maps.

Sampling of river water is done in accordance with SNI 6989.57: 2008, using boat and water sampler tool. Samples were collected at each monitoring station divided into 3 dots across the river and each at three depth layers to be combined (composite). Subsequently the water sample for the BOD parameter was directly transferred into a $500 \mathrm{ml}$ BOD bottle while for other parameters into the 2.5 liter plastic jewel that has been labeled. Water quality were analyzed insitu and exsitu. Temperature, TDS and salinity parameters using Extech instruments, ExStick EC 400; pH with pH meter type ATC (pH-009 (I) A; DO with LUTRON DO meter DO5509 , while other parameters were analyzed exsitu in Sucofindo Laboratory Pontianak.

Measurement of vertical distribution of salinity at each monitoring station. Samples were taken at three layers of depth ie surface layer (0.2d), middle (0.6d) and bottom of river $(0.8 \mathrm{~d})$ with water sampler and examined its salinity by insitu with Extech instruments, ExStick EC 400.Cross-sectional measurements of river and river depth at each monitoring station are done by boat, GPS and echosounder. Measurement of water level elevation using HOBO onset water level logger S / N: 10949770 installed in intake of Pontianak City WTP.

Water quality data will be analyzed by statistical regression-correlation method to determine the effect of tides on water quality and its relation to river discharge and hydrological condition.

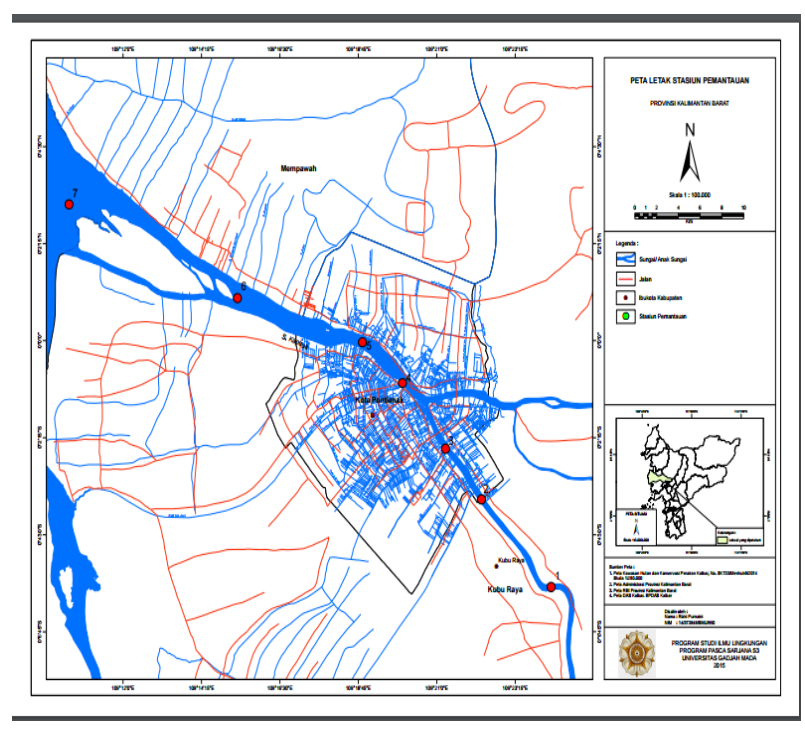

Fig. 1. The map of sampling Location

\section{Results}

The results of tidal observations at the study sites in August 2016 and January 2017, the tidal type in the Kapuas Kecil River is mixed tide prevailing diurnal, in one day there is one tide but sometimes temporarily occurs twice tide with very different heights and periods (Fig. 2 \&3). Maximum water level elevation of Kapuas Kecil River in August 2016: $1.6 \mathrm{~m}$ at high tide and 0.5 $\mathrm{m}$ at low tide, while January 2017: $1.7 \mathrm{~m}$ at high tide and $0.4 \mathrm{~m}$ at low tide [3].

\subsection{Salinity distribution in Kapuas Kecil River downstream}

The horizontal salinity distribution in Kapuas Kecil river from upstream to downstream tends to increase at high tide (Fig. 4). The effect of tides on salinity increases significantly with the increasing distance of observation stations progressively toward the downstream / river estuary. Distance of sea water is relatively far, approximately $10 \mathrm{~km}$ upstream (monitoring station 6), salinity value at this location is about 6 ppt. In the longitudinal direction, the salinity will increase or increase along with the distance from the upstream to the downstream or vice versa due to the influence of tidal, estuary characteristics, and river discharge [1]. 




Fig. 3. Tidal elevation in Kapuas Kecil River January 2017

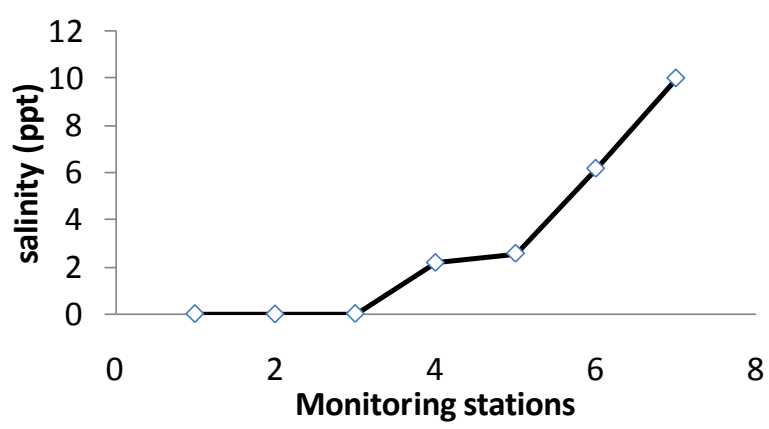

Fig. 4. The horizontal salinity distribution in Kapuas Kecil river

The vertical salinity distribution in the three depth layers of each monitoring station at the study sites is shown in Fig. $5 \& 6$. Layer depth of the river affects the salinity distribution vertically. Salinity increases with depth, due to the greater sea-water density than freshwater, so that the salinity value will increase on the bottom of the river.

Based on the salinity structure, Kapuas Kecil River estuary has a "partially mixed" estuary type. This is based on the characteristics of this estuary type described in Triatmodjo, salinity varies in longitudinal and vertical directions. In the longitudinal direction, the salinity is reduced from the mouth of the river to the upstream, while in the vertical direction decreases from the base to the surface.
Salinitas (ppm)

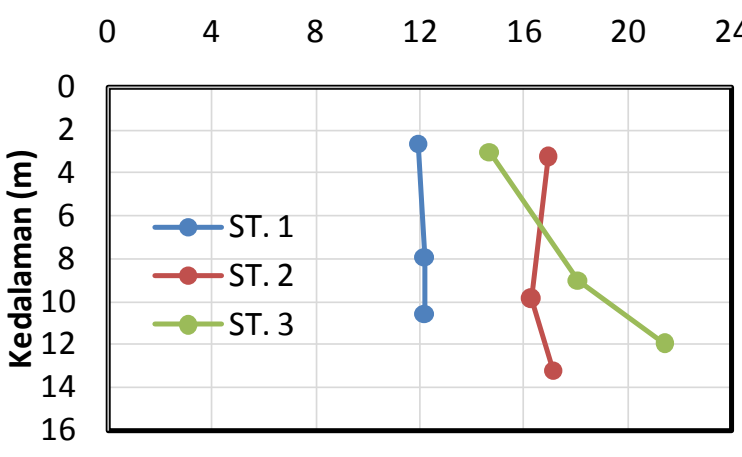

Fig. 5. The vertical salinity distribution in uptream site

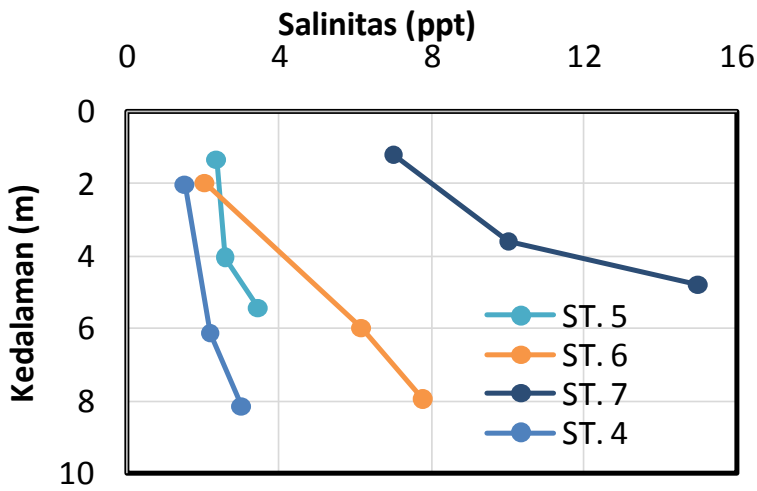

Fig. 6. The vertical salinity distribution in downstream site

\subsection{Water Quality of Kapuas Kecil River downstream}

Water quality of Kapuas Kecil River must conform with the criteria of water quality class I PP RI No. 82/2001, that is, water which can be used for drinking water, and / or for other uses which require the same water quality as the activity [4].

Insitu data measurement showed that temperature 29 $-34^{\circ} \mathrm{C}$ and $\mathrm{pH}$ value $6,0-7,8$.

BOD5 and COD levels during the rainy and dry season at high and low tides have exceeded the water quality criteria established for Class I, ie BOD $2 \mathrm{mg} / 1$ and COD $10 \mathrm{mg} / \mathrm{l}$, with upstream to downstream trend increasingly (Fig.7\&8). High levels of BOD and COD in the study sites indicate that river water is contaminated by organic material derived from discharges entering the river along the stream, while self purification of the river is exceeded. Most of the discharges coming into the river come from urban runoff, domestic waste settlements, waste of trade and services activities (markets, hotels, restaurants, malls), large industrial wastes (factories) along streams and small industrial waste (home industry).

The results of DO insitu measurements at the study sites from upstream to downstream during the rainy and dry seasons at high and low tide generally fluctuate and still meet the water quality criteria set for Class I of minimum $6 \mathrm{mg} / 1$. Dissolved oxygen levels fluctuate on 
a daily and seasonal basis, depending on the mixing and movement of water masses, photosynthesis, respiration and effluent activity into water bodies [5].

$\mathrm{DO}$ values should be inversely proportional to BOD and COD values, since BOD and COD represent the total amount of oxygen required to oxidize organic materials either by microorganisms or chemically. The higher the value of BOD and COD then the DO value will be lower. The value of DO measurements obtained in the field is in fact incompatible with the logic of existing theory. This can be caused by human error factors at the time of measurement or factor of the tool [6].

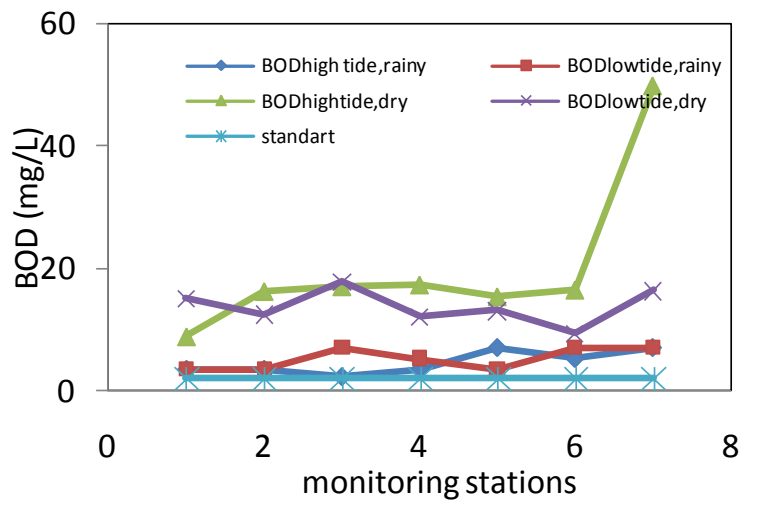

Fig. 7. BOD content in Kapuas Kecil River

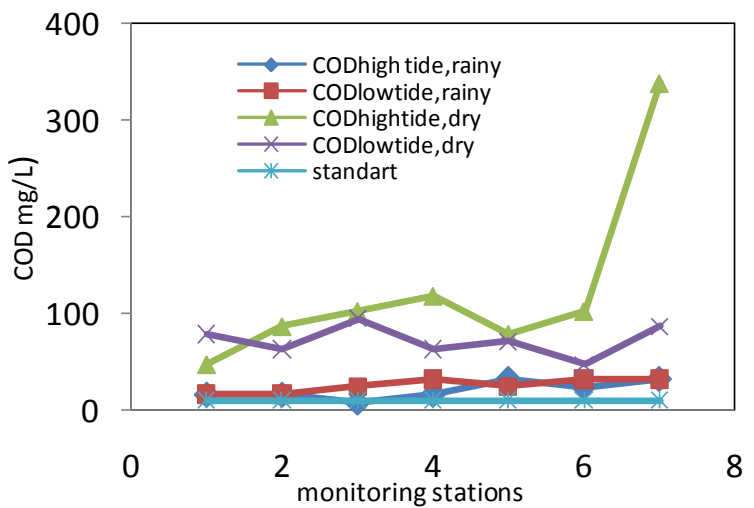

Fig. 8. COD content in Kapuas Kecil River

Nitrate value at research location during rainy season and dry season at high and low tide generally conform with water quality criteria for Class I that is 10 $\mathrm{mg} / 1$. Nitrate levels greater than $5 \mathrm{mg} / 1$ illustrate the occurrence of anthropogenic contamination derived from human activities and animal feces [5].

The total value of phosphorus at the study sites during the rainy and dry seasons at high and low tide has exceeded the Class I water quality criteria of $0.2 \mathrm{mg}$ / 1. Anthropogenic sources of phosphorus are industrial and domestic waste, ie phosphorus derived from detergents. Runoff from agricultural areas using fertilizers also contributes substantially to the presence of phosphorus [5].

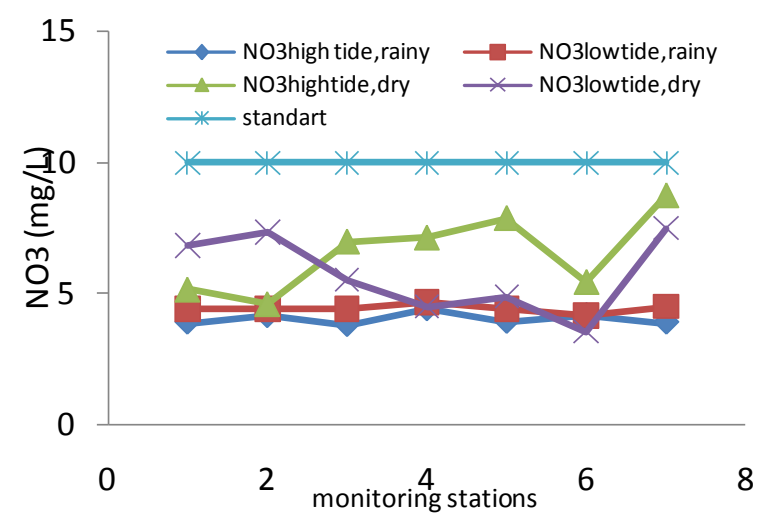

Fig. 9NO3 content in Kapuas Kecil River

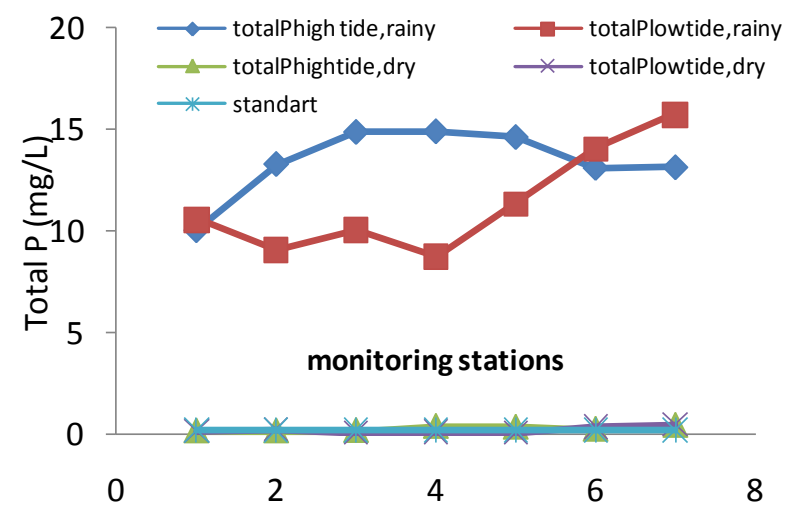

Fig. 10. Total $P$ content in Kapuas Kecil River

The value of TSS in the study sites from upstream to downstream during the rainy and dry seasons at high and low tide generally fluctuates, and exceeds the water quality criteria set for Class I of $50 \mathrm{mg} / 1$. TSS (Total Suspended solid) consists of mud and fine sands and microorganisms, mainly due to soil erosion or soil erosion brought to water bodies [5].

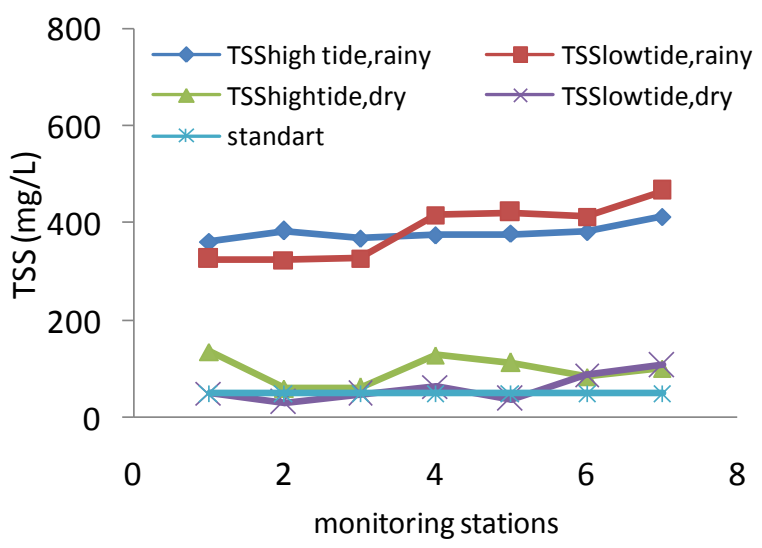

Fig. 11. TSS content in Kapuas Kecil River

TDS (Total Dissolved Solid) describes dissolved ions in water. The value of TDS at the study sites during 
the rainy and dry seasons at high and low tide is generally increasing downstream and exceeds the Class I water quality criteria of $1,000 \mathrm{mg} / 1$, but at the low tide, conform with the criteria of Class I water quality. Increasing the value of TDS at downstream indicates the effect of tides that enter the river, high TDS value also shows a high salinity value [5].

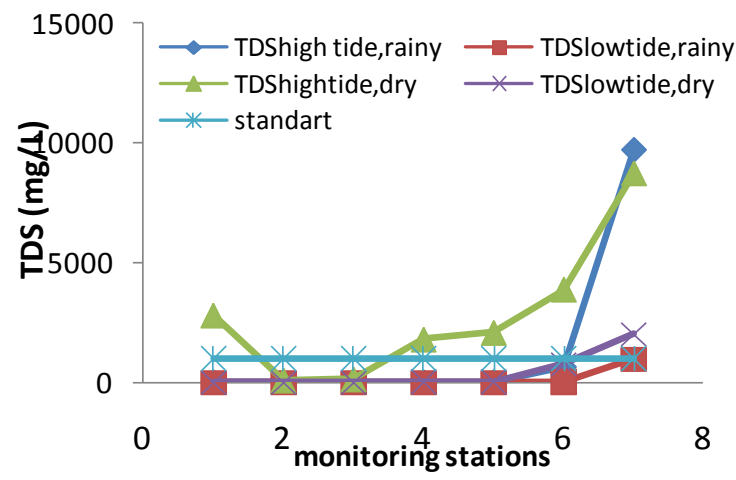

Fig. 12. TDS content in Kapuas Kecil River

The result of pollution index calculation to determine the status of water quality of Kapuas Kecil River based on KepMenLH 115/2003 found that river condition in general "mild to medium pollutant" [7]. This indicates that there has been a decrease in water quality of Kapuas Kecil River so that it is not in accordance with its intended to be utilized as raw water for drinking water, so it is necessary efforts to water quality management and water pollution control.

\subsection{Tidal Relationship to Distance Salinity}

The results of analysis using multiple linear regression found that there is a relationship between tidal elevation and distance to water quality of $91 \%$, seen from the correlation coefficient (R) as shown in Fig. Next got the coefficient of determination (adjusted $\mathrm{R}$ square) = 0.760 ; This value as a whole indicates that the independent variable (tidal and distance elevation) influence to water quality (TDS value) equal to $76 \%$, while the rest influenced by other variable not examined in this research (Table 1).

Table 1.Multiple regression analys is results

\begin{tabular}{|l|r|r|r|r|r|}
\hline Model & \multicolumn{1}{|c|}{ R } & R Square & $\begin{array}{c}\text { Adjusted } \\
\text { R Square }\end{array}$ & $\begin{array}{l}\text { Std. Error of } \\
\text { the Estimate }\end{array}$ & $\begin{array}{l}\text { Durbin- } \\
\text { Watson }\end{array}$ \\
\hline 1 & $.916^{\mathrm{a}}$ & .840 & .760 & 1783.42781 & 2.447 \\
\hline
\end{tabular}

a. Predictors: (Constant), Tidal Rain level (X2ph), Distance (X1)

b. Dependent Variable: TDS Tidal Rain (Yph)

\section{Conclusion}

- Based on its salinity structure, the Kapuas Kecil estuary has a "partially mixed" estuary type, salinity varies in longitudinal and vertical directions.

- In general. the water quality of the Kapuas Kecil River has exceeded the criteria of first class water quality, ie water that can be used for drinking water.

- Status of water quality of Kapuas Kecil River based on calculation of pollution index shows the condition of the river "mild contamination" to "medium pollutant".

- The result of multiple linear regression analysis got the value of coefficient of determination (adjusted $\mathrm{R}$ square $)=0,760$, which overall showed that tidal and distance influence to water quality (TDS value) equal to $76 \%$.

\section{Acknowledgements}

This research was supported by Doctor Dissertation grant from Directorate of Research and Community Service, Directorate General of Research and Development Reinforcement, Ministry of Research, Technology and Higher Education, In accordance with the Contract of Research Number: 107 / SP2H / LT / DRPM / IV / 2017 April 3, 2017.

\section{References}

1. B. Triatmodjo, Teknik Pantai, (1999)

2. Z. G. Ji..River Fate and Transport, chapter in J.S. Gulliver (ed.), Transport and Fate of Chemicals in the Environment, (2012)

3. Dishidros TNI AL Indonesia, Daftar Pasang Surut Kepulauan Indonesia. (2016).

4. Peraturan Pemerintah No. 82 tentang Pengelolaan Kualitas Air dan Pengendalian Pencemaran $\operatorname{Air}(2001)$

5. H. Effendi, Telaah Kualitas Air; Bagi Pengelolaan Sumberdaya dan Lingkungan Perairan(2003)

6. Salmin, Oksigen Terlarut (DO) dan Kebutuhan Oksigen Biologi (BOD) Sebagai Salah Satu Indikator Untuk Menentukan Kualitas Perairan. Oseana, Volume XXX, No. 3, 21-26(2005)

7. Keputusan Menteri Negara Lingkungan Hidup No.115 Tahun tentang Pedoman Penentuan Status Mutu Air, (2003) 